\title{
Estimation of red deer (Cervus elaphus) post mortal interval based on the biochemical parameters of vitreous fluid using linear regression analyses
}

\section{Krešimir Severin ${ }^{1 *}$, Petar Džaja ${ }^{1}$, Marcela Šperanda ${ }^{2}$, Mislav Đidara ${ }^{2}$, Dean Konjevićc 3 , Edin Šatrović ${ }^{4}$, and Kristina Starčević ${ }^{1}$}

\author{
${ }^{1}$ Department of Forensic and State Veterinary Medicine, Faculty of Veterinary Medicine, University of Zagreb, \\ Zagreb, Croatia \\ ${ }^{2}$ Department of Animal Sciences, Faculty of Agriculture, University of Osijek, Osijek, Croatia \\ ${ }^{3}$ Department of Veterinary Economics and Epidemiology, Faculty of Veterinary Medicine, University of \\ Zagreb, Zagreb, Croatia \\ ${ }^{4}$ Department of State and Forensic Veterinary Medicine, Veterinary Faculty Sarajevo, University of Sarajevo, \\ Sarajevo, Bosnia and Herzegovina
}

\begin{abstract}
SEVERIN, K., P. DŽAJA, M. ŠPERANDA, M. ĐIDARA, D. KONJEVIĆ, E. ŠATROVIĆ, K. STARČEVIĆ: Estimation of red deer (Cervus elaphus) post mortal interval based on the biochemical parameters of vitreous fluid using linear regression analyses. Vet. arhiv 88, 511-519, 2018.
\end{abstract}

\section{ABSTRACT}

Vitreous fluid is a stable biological fluid, which is well-protected from contamination and post mortem degradation, which makes it suitable in forensic pathology for determination of the post mortem interval (PMI). The present study was conducted to discover the correlation between increasing PMI and levels of various vitreous biochemical parameters (sodium, calcium, magnesium, chloride, potassium, phosphor, AST, urea, creatinine, total protein, glucose, total cholesterol). The estimation of PMI in red deer is of great interest in cases of illegal hunting. The vitreous humour samples were collected from six red deer carcasses. The eyes were enucleated, covered by parafilm and aluminium foil, packed in a small container and maintained at $+4{ }^{\circ} \mathrm{C}$. Sampling of vitreous fluid was done again at 8,10 and then regularly each 10 hours until finally 90 hours after death. A significant linear correlation was found for potassium, sodium and chloride $(\mathrm{P}<0.0001)$. The present study revealed that biochemical analysis of vitreous fluid could be used to determine post mortem interval in red deer.

Key words: vitreous fluid; potassium; sodium; chloride; red deer

\footnotetext{
*Corresponding author:

Assoc. Prof. Krešimir Severin, Department of Forensic and State Veterinary Medicine, Faculty of Veterinary Medicine, University of Zagreb, Heinzelova 55, 10000 Zagreb, Croatia, Phone: +385 12390 125; Fax: +385 12441 390; E-mail: severin@vef.hr
} 
K. Severin et al.: Estimation of red deer (Cervus elaphus) post mortal interval

\section{Introduction}

Determination of the post mortem interval (PMI) is an important parameter in forensic pathology and represents one of the most frequent questions addressed to forensic experts in a court of law. Determination of the PMI is complex due to many unpredictable changes governed by endogenous and exogenous factors (COE, 1977). Therefore, many studies are trying to resolve these factors and to determine PMI with the highest possible accuracy. The use of biochemistry in the post mortem period has become an essential procedure in forensic pathology and considerable progress has been made in this field over the past decades (PALMIERE and MANGIN, 2012; CHANDRAKANTH et al., 2013). Many different chemical reactions begin immediately or shortly after death in various body fluids, making the relationship between biochemistry values and PMI more difficult to interpret. However, the fact that the changes to each biochemical parameter have different rates of progression could help forensics to determine the PMI more accurately. Vitreous fluid shows excellent post mortem stability in comparison to other body fluids available for biochemical examination (COE, 1969). Decelerated diffusion and anatomical protection enables the preservation of vitreous integrity and makes it less susceptible to bacterial degradation.

There have been many studies on humans dealing with an estimation of time of death based on the differences in biochemical values, mainly of potassium, with or without adjustments for ambient temperature (ADJUTANTIS and COUTSELINIS, 1972; MADEA et al., 1989; MADEA et al., 1994; JAMES et al., 1997; MUNOZ BARUS et al., 2002; ROGNUM et al., 2016). However, there is still a limited number of studies dealing with determination of the PMI in wild animals. The formulas for determination of the PMI in humans cannot be applied to animals because there is considerable species variation in the absolute values of the electrolyte concentrations in the vitreous fluid (BITO and DAVSON, 1964; McLAUGHLIN and McLAUGHLIN, 1987). The accurate determination of the post-mortem interval in the red deer population allows establishment of which animals have been killed in illegal hunting.

The aim of this study was to evaluate the correlation between the vitreous fluid concentrations of different biochemical parameters ( $\mathrm{Na}, \mathrm{K}, \mathrm{Cl}$, AST, Creatinine, $\mathrm{Mg}$, Glucose, Urea, P and Ca) and PMI over a period of 90 hours. The obtained results should provide preliminary data on PMI estimation in red deer.

\section{Materials and methods}

In the present study, vitreous fluid was obtained from the 6 deer collected during the regular hunting season. As soon as possible, after receiving the carcasses from the hunting grounds, the eyeballs were enucleated by holding them with forceps and cutting the optic nerve with scissors. To protect the eyeball from adverse external factors (drying, bacterial 
contamination, etc.) each eyeball was covered by parafilm and aluminium foil, packed in a small container and maintained at $+4{ }^{\circ} \mathrm{C}$. Sampling of vitreous fluid for biochemical analysis was performed using a needle which was inserted at the lateral angle of the eyeball, so that the tip of the needle was placed into the centre of the eyeball. Sampling of the vitreous fluid was performed at 8 and 10 hours and thereafter every 10 hours up to a total of 90 hours after death. During the sampling, $200 \mu \mathrm{L}$ of vitreous fluid was aspirated and transferred to Eppendorf tubes. The samples were then centrifuged at $1650 \mathrm{xg}$ for 15 min at $4{ }^{\circ} \mathrm{C}$ until analysed further.

The levels of total protein, urea, total bilirubin, AST, creatinine, glucose, $\mathrm{Mg}, \mathrm{Ca}$ and P were assayed by an automatic analyser (SABA-18, Analyzer Medical System, Roma, 00153, Italy).

The samples was analysed for electrolytes $\left(\mathrm{Na}^{+}, \mathrm{K}^{+}, \mathrm{Cl}-\right.$ ) by RapidLab 348 (Bayer, Leverkusen, 51373, Germany) on the ion selective electrode principle.

For each biochemical parameter, the mean values of both eyes were used for further statistical analysis.

Statistical analysis. Data were analysed using the Statistica software (STATISTICA 2010 program, Tulsa, USA), GraphPad Prism 7.0 and MetaboAnalyst 3.0. Simple linear regression analysis and Spearman's rank correlation coefficient were used to study the relationships between the concentrations of biochemical parameters in the vitreous liquor and PMI. P values less than 0.01 were considered significant.

\section{Results}

The results of the biochemical and regression analysis are presented in Table 1 and Fig. 1. Vitreous sodium and chloride levels showed a significant $(\mathrm{P}<0.01)$ decrease at all intervals up to 90 hours post mortem as compared with the initial concentration ( 8 h). A strong correlation was noticed between the sodium levels and PMI $\left(R^{2}=0.842\right.$, $\mathrm{P}<0.0001)$. The same pattern was also visible for the chloride values, also with a high correlation $\left(\mathrm{R}^{2}=0.873, \mathrm{P}<0.0001\right)$ with the PMI. The vitreous potassium concentration in our study showed a gradual rise from the mean concentration of $7.25 \mathrm{mmol} / \mathrm{L}$ to $23.28 \mathrm{mmol} / \mathrm{L}$ at $90 \mathrm{~h} \mathrm{p} / \mathrm{m}$. The analysis of other biochemical parameters $(\mathrm{Mg}, \mathrm{Ca}$, total bilirubin, creatinine, AST, urea, total protein) showed a moderate to low correlation with PMI $\left(\mathrm{R}^{2}=0.15-0.5\right)$. The level of glucose present in the vitreous decreased significantly $(\mathrm{P}<0.01)$ during the early post mortem period. 
K. Severin et al.: Estimation of red deer (Cervus elaphus) post mortal interval

\begin{tabular}{|c|c|c|c|c|c|c|c|c|c|c|c|c|c|}
\hline 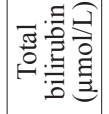 & $\begin{array}{c}0 \\
0 \\
0\end{array}$ & 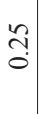 & 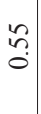 & ڤે? & $\stackrel{n}{a}$ & $\begin{array}{l}\infty \\
0 \\
0 \\
0\end{array}$ & $\stackrel{n}{n}$ & $\hat{a}$ & $\begin{array}{l}\hat{2} \\
\dot{0}\end{array}$ & $\stackrel{n}{i}$ & $\begin{array}{c}\stackrel{i}{n} \\
i\end{array}$ & 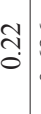 & $\begin{array}{l}0 \\
\text { oे } \\
\stackrel{0}{0}\end{array}$ \\
\hline 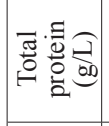 & 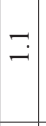 & $\stackrel{\overbrace{}}{\unlhd}$ & $\stackrel{n}{=}$ & $\begin{array}{c}q \\
q \\
i\end{array}$ & $\frac{\bar{m}}{m}$ & $\begin{array}{l}\stackrel{D}{b} \\
\dot{m}\end{array}$ & $\begin{array}{l}\tilde{\sigma} \\
\text { in }\end{array}$ & $\begin{array}{l}2 \\
\check{n} \\
\end{array}$ & నু & $\begin{array}{l}n \\
\dot{\Xi} \\
\dot{\Xi}\end{array}$ & $\begin{array}{l}8 \\
\text { in }\end{array}$ & 文 & $\frac{\infty}{\stackrel{\infty}{\circ}}$ \\
\hline 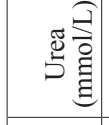 & $\begin{array}{l}n \\
n \\
n\end{array}$ & 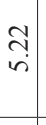 & $\begin{array}{l}n \\
n \\
i\end{array}$ & $\begin{array}{l}\vec{b} \\
\dot{n}\end{array}$ & 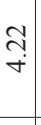 & $\begin{array}{l}\tilde{f} \\
\stackrel{+}{*}\end{array}$ & $\overline{\dot{\sigma}}$ & $\begin{array}{l}\tilde{D} \\
\dot{n} \\
\dot{n}\end{array}$ & : & $\begin{array}{l}\stackrel{8}{\Xi} \\
\end{array}$ & $\begin{array}{l}\vec{b} \\
\dot{\Xi}\end{array}$ & $\begin{array}{c}\text { ?ै } \\
0 \\
0\end{array}$ & 竎 \\
\hline 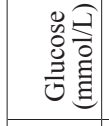 & $\stackrel{g}{g}$ & సે & $\bar{\Xi}$ & $\stackrel{0}{\circ}$ & $\underset{0}{J}$ & $\overrightarrow{\widetilde{o}}$ & $\begin{array}{l}0 \\
\stackrel{0}{0}\end{array}$ & $\begin{array}{l}\overrightarrow{0} \\
\dot{0}\end{array}$ & $\begin{array}{l}2 \\
\dot{0}\end{array}$ & $\vec{\square}$ & $\begin{array}{ll}\Xi \\
\\
0\end{array}$ & $\begin{array}{l}+ \\
\text { o. }\end{array}$ & $\begin{array}{l}\overline{8} \\
\dot{8} \\
\dot{\nabla}\end{array}$ \\
\hline 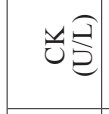 & $\begin{array}{l}0 \\
\ddot{v}\end{array}$ & $\begin{array}{c}0 \\
\dot{b} \\
i\end{array}$ & i. & in & $\stackrel{\circ}{=}$ & $\begin{array}{l}\infty \\
\dot{n}\end{array}$ & 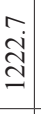 & 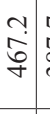 & $\stackrel{r}{\substack{\infty \\
\infty}}$ & $\begin{array}{c}0 \\
\dot{m} \\
\underline{\Xi}\end{array}$ & 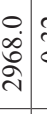 & & $\begin{array}{l}\text { Oे } \\
\text { ?ె? }\end{array}$ \\
\hline$\stackrel{S}{S}$ & $\begin{array}{l}\dot{\partial} \\
\dot{g}\end{array}$ & $\begin{array}{l}\vec{c} \\
\vec{a}\end{array}$ & $\begin{array}{l}\infty \\
2 \\
\check{\alpha}\end{array}$ & 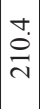 & $\begin{array}{l}\vec{i} \\
\underset{n}{2}\end{array}$ & $\begin{array}{l}\stackrel{0}{\dot{j}} \\
\text { in }\end{array}$ & 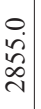 & $\begin{array}{l}\infty \\
\stackrel{\infty}{n} \\
\end{array}$ & \begin{tabular}{l|l}
$\vec{\infty}$ & \\
$\stackrel{\Xi}{=}$ &
\end{tabular} & 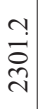 & స్ర్లి| & $\stackrel{\text { Tे }}{0}$ & $\overline{0}$ \\
\hline 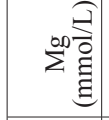 & à & ఏ. & $\stackrel{n}{a}$ & $\begin{array}{l} \pm \\
\infty \\
0 \\
0\end{array}$ & $\stackrel{5}{0}$ & $\begin{array}{l}\mathcal{C} \\
\infty \\
0 \\
0\end{array}$ & $\begin{array}{l}\hat{b} \\
\dot{0}\end{array}$ & 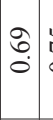 & $\begin{array}{l}n \\
\mathfrak{c} \\
\dot{0}\end{array}$ & $\begin{array}{c}\tilde{\sigma} \\
\sigma \\
-\end{array}$ & $\begin{array}{l}n \\
\infty \\
\infty \\
\vdots \\
\vdots\end{array}$ & & 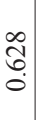 \\
\hline ن & $\hat{\alpha}$ & $\begin{array}{l}0 \\
\vdots \\
0\end{array}$ & $\begin{array}{l}\hat{b} \\
\dot{0}\end{array}$ & $\begin{array}{l}0 \\
\dot{b} \\
0\end{array}$ & $\begin{array}{l}\tilde{b} \\
0 \\
0\end{array}$ & $\begin{array}{l}\tilde{b} \\
\stackrel{0}{0}\end{array}$ & $\begin{array}{l}\text { : } \\
\stackrel{0}{0}\end{array}$ & $\mid$ & $\begin{array}{c}r \\
\stackrel{0}{0} \\
\dot{0}\end{array}$ & $\begin{array}{l}\infty \\
\stackrel{0}{0} \\
0\end{array}$ & $\begin{array}{l}? \\
\dot{0}\end{array}$ & & $\begin{array}{l}\infty \\
\infty \\
\infty \\
0\end{array}$ \\
\hline 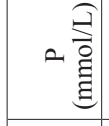 & $\stackrel{1}{2}$ & กิ & $\tilde{n}$ & $\begin{array}{l}1 \\
\tilde{b} \\
0\end{array}$ & $\begin{array}{c}\infty \\
\infty \\
0 \\
0\end{array}$ & $\underline{n}$ & $\tilde{n}$ & $\begin{array}{l}\stackrel{0}{r} \\
\dot{m}\end{array}$ & $\begin{array}{l}\mathcal{V} \\
\dot{+}\end{array}$ & ڤ్రి & 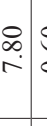 & & $\begin{array}{l}\tilde{1} \\
\tilde{8} \\
0 \\
0\end{array}$ \\
\hline 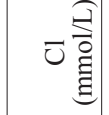 & $\begin{array}{c}0 \\
\ddot{\sim} \\
-\end{array}$ & $\stackrel{\circ}{\stackrel{0}{二}}$ & $\begin{array}{l}\because \\
\triangleq\end{array}$ & $\begin{array}{l}0 \\
\stackrel{0}{\Xi} \\
=\end{array}$ & $\begin{array}{l}\stackrel{\dot{Q}}{\Xi} \\
\end{array}$ & $\begin{array}{l}\stackrel{1}{n} \\
=\end{array}$ & 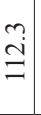 & $\stackrel{\infty}{0}$ & $\begin{array}{cc}c & 5 \\
\infty \\
0\end{array}$ & $\begin{array}{l}0 \\
\dot{\circ} \\
0\end{array}$ & 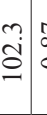 & & $\begin{array}{l}\overrightarrow{8} \\
\dot{0} \\
\dot{\hat{q}} \\
\mathrm{v}\end{array}$ \\
\hline 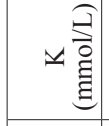 & $\bar{n}$ & $\underset{\square}{ \pm}$ & 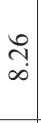 & $\begin{array}{l}\stackrel{0}{0} \\
\stackrel{0}{0}\end{array}$ & $\begin{array}{l}\tilde{\sigma} \\
\text { I } \\
-\end{array}$ & $\begin{array}{l}\tilde{n} \\
\tilde{n} \\
\end{array}$ & $\begin{array}{c}\tilde{\sigma} \\
\hat{\sigma}\end{array}$ & $\left|\begin{array}{c}\infty \\
\infty \\
\infty \\
-\end{array}\right|$ & $\overline{\grave{\Omega}}$ & $\begin{array}{l}\stackrel{n}{0} \\
\vec{\lambda}\end{array}$ & $\begin{array}{l}m \\
\vec{\lambda}\end{array}$ & $\begin{array}{l}\infty \\
\dot{0} \\
\dot{0}\end{array}$ & $\begin{array}{l}8 \\
\grave{\delta} \\
\dot{\nabla} \\
\dot{v}\end{array}$. \\
\hline 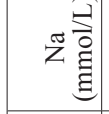 & $\begin{array}{l}0 \\
0 \\
\dot{0} \\
\pm \\
\end{array}$ & $\begin{array}{l}0 \\
\dot{y} \\
\dot{J}\end{array}$ & $\begin{array}{l}0 \\
\dot{\vec{J}} \\
\end{array}$ & $\begin{array}{l}m \\
\infty \\
m \\
-\end{array} \mid$ & $\begin{array}{l}0 \\
\dot{9} \\
\dot{9}\end{array}$ & $\begin{array}{l}n \\
0 \\
n \\
n\end{array}$ & $\begin{array}{l}\tilde{n} \\
\tilde{\Omega}\end{array}$ & $\stackrel{0}{\dot{m}}$ & $\stackrel{0}{\grave{\Xi}}$ & $\begin{array}{l}\infty \\
\stackrel{\Delta}{\Xi} \\
\end{array}$ & $\begin{array}{l}\stackrel{0}{\dot{a}} \\
\overrightarrow{\mathrm{I}}\end{array}$ & \begin{tabular}{l}
\multirow{\infty}{\infty}{} \\
$\dot{0}$
\end{tabular} & $\begin{array}{l}\overline{8} \\
\vdots \\
\dot{\nabla} \\
\dot{v}\end{array}$. \\
\hline 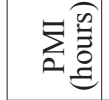 & $\infty$ & 인 & $\simeq$ & సి & ¿ & q & in & 8 & $\therefore 8$ & $\infty$ & 8 & $\simeq$ & . \\
\hline
\end{tabular}


Sodium

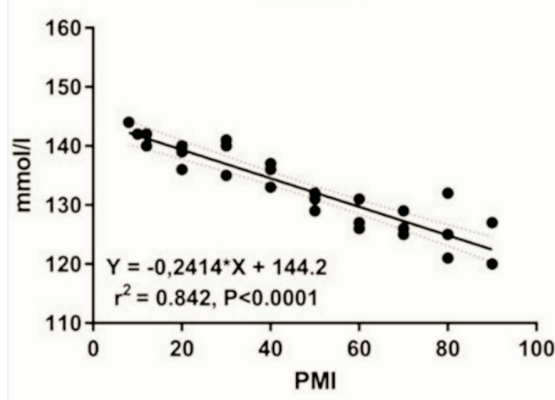

Chloride

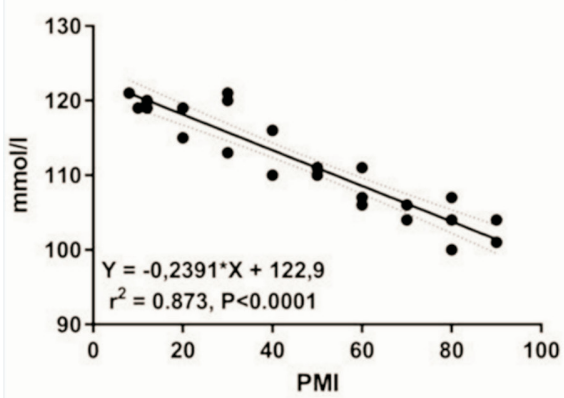

Potassium

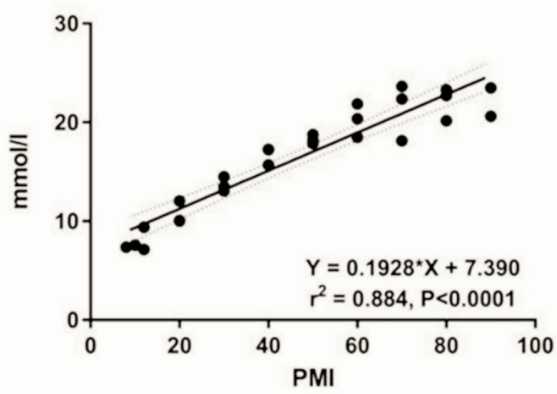

Compounds correlated with PMI

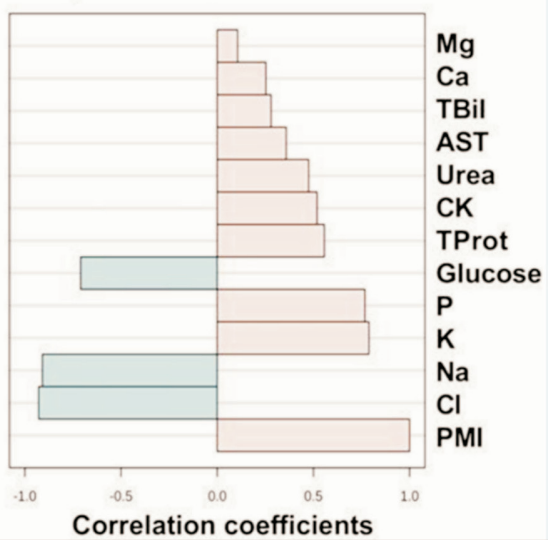

Fig. 1. Linear regression analyses of the PMI with vitreous sodium, potassium and chloride concentrations $(\mathrm{P}<0.001)$

\section{Discussion}

The present study revealed a high correlation between the levels of vitreous electrolytes: $\mathrm{Na}^{+}, \mathrm{Cl}^{-}$and $\mathrm{K}^{+}$and PMI (Fig. 1). The analytical method used in this study was an ion selective electrode for determination of sodium, potassium, and chloride concentrations. According to the literature, this is the method of choice and is the best solution to reduce error when analysing fluid by flame photometry (TUMRAMA et al., 2011). After death, active and selective membrane transport stops, and the loss begins of selective membrane permeability and diffusion of ions and other parameters, according to their concentration gradients. Although stable for a long time in the post-mortem period, certain vitreous elements will change with diffusion from the retinal cells (INGHAM and BYARD, 2009). In the literature, the levels of sodium and chloride were found to 
be relatively stable in the early post-mortem period, and therefore they may be useful for determination of the mechanism of death (BITO and DAVSON, 1964; INGHAM and BYARD, 2009). For example, the concentration of ante-mortem serum sodium and chloride are reflected in post-mortem vitreous values, making it possible to diagnose hyponatremia or hypernatremia at the time of death (INGHAM and BYARD, 2009). The post-mortem changes in vitreous sodium and chloride levels have been studied extensively by different authors, but there is no real consensus about the post-mortem changes in these electrolytes. ZIGH et al. 2016 stated that the reason for the postmortem decrease in vitreous sodium and chloride levels is most likely the diffusion of these electrolytes into the surrounding cells of the retina and choroid, due to loss of cell integrity. How post-mortem vitreous sodium and chloride levels should be interpreted, still remains inconclusive.

A linear regression analysis of cations and anions of interest is presented in Fig. 1. Our findings are in agreement with various studies conducted on dogs, cattle, deer and pigs (BRZEZIÑSKI and GODLEWSKI, 2004). The post-mortem increase in vitreous potassium levels has been widely used in forensics to estimate the time of death of humans and animals (AHI and GARG, 2001; COE, 1989; COE, 1972). Under physiological conditions, potassium is prevalent in high and similar levels in all cells of the body (BANIAK et al., 2015). Numerous hypotheses have been established for the rise of potassium concentrations with the time of death. One suggestion was that the source of influx of potassium into the vitreous liquid are the vascular choroid and retinal lining cells (BANIAK et al., 2015). In contrast, other authors suggested that the postmortem breakdown of active membrane causes the halt of all transport, resulting in the loss of selective permeability and diffusion of ions and other parameters according to the concentration gradient (JAMES et al., 1997; MADEA et al., 1989; MADEA et al., 1994; MUNOZ BARUS et al., 2002; ROGNUM et al., 2016). The presence of a higher concentration of potassium in the intracellular matrix supports this hypothesis (MADEA et al., 1994).

The analysis of $\mathrm{Mg}, \mathrm{Ca}$, total bilirubin, creatinine, AST, urea, total protein showed no significant differences with the increase in PMI. Similar results of these parameters after death were also found for humans (GURLER et al., 2016). Nevertheless, the post-mortem urea and creatinine concentrations correlate with the ante-mortem serum levels of these parameters, and they could give a valuable insight into the metabolic status before death (HANNA et al., 1990; ZHU et al., 2007).

The concentration of glucose present in the vitreous decreased significantly during the early post mortem period, probably due to the increase in the rate of anaerobic glycolysis. The drop in glucose concentration stops between 24-30 hours after death, as evident from the obtained results. This trend was observed in previous studies as well 
K. Severin et al.: Estimation of red deer (Cervus elaphus) post mortal interval

(ZILG et al., 2009). Most likely, the glucose in the vitreous will be consumed by the surviving hyalocytes and inner retinal cells in the early post-mortem phase and then an equilibration which follows gradually occurs between the intra- and extracellular spaces. These changes exclude glucose as a tool for PMI determination (COE, 1972; YAHIA and ABD EL-HAKIEM, 2014; TUMRAMA et al., 2011).

\section{Conclusion}

Biochemical markers such as potassium, sodium and chloride show a significant correlation with the PMI. The results obtained indicate the validity of using vitreous potassium in the determination of the time of death in red deer. These parameters could be valuable for PMI determination in forensic cases, as well as in monitoring wildlife health.

\section{References}

ADJUTANTIS, G., A. COUTSELINIS (1972): Estimation of the time of death by potassium levels in the vitreous humour. Forensic Sci. 1, 55-60.

DOI: 10.1016/0300-9432(72)90147-1

AHI, R. S., V. GARG (2001): Role of vitreous potassium level in estimating postmortem interval and the factors affecting it. J. Clin. Diagn. Res. 5, 13-15.

BANIAK, N., G. CAMPOS-BANIAK, A. MULLA, J. KALRA (2015): Vitreous humor: a short review on post-mortem applications. J. Clin. Exp. Pathol. 4, 1-7.

DOI: $10.4172 / 2161-0681.1000199$

BITO, L., H. DAVSON (1964): Steady-state concentrations of potassium in the ocular fluids. Exp. Eye Res. 3, 283-297.

DOI: $10.1016 / \mathrm{S} 0014-4835(64) 80021-X$

BRZEZIÑSKI, P. M., A. GODLEWSKI (2004): Assessment of potassium and sodium ion concentrations in the vitreous humour of swine isolated eyeballs after organism death. Rocz. Akad. Med. Bialymst. 49, 161-163.

CHANDRAKANTH, H. V., T. KANCHAN, B. M. BALARAJ, H. S. VIRUPAKSHA, T. N. CHANDRASHEKAR (2013): Postmortem vitreous chemistry - an evaluation of sodium, potassium and chloride levels in estimation of time since death (during the first $36 \mathrm{~h}$ after death). J. For. Legal Med. 20, 211-216.

DOI: $10.1016 /$ j.jflm.2012.09.001

COE, J. I. (1969): Postmortem chemistries on human vitreous humor. Am. J. Clin. Pathol. 51, 741-750. DOI: $10.1093 /$ ajcp/51.6.741

COE, J. I. (1972): Use of chemical determinations on vitreous humor in forensic pathology. J. For. Sci. $17,541-546$.

DOI: $10.1520 / J F S 10142 J$ 
K. Severin et al.: Estimation of red deer (Cervus elaphus) post mortal interval

COE, J. I. (1977): Postmortem chemistry of blood, cerebrospinal fluid, and vitreous humor. Leg. Med. Ann. 1976, 55-92.

COE, J. I., (1989): Vitreous potassium as a measurement of the postmortem interval: an historical review and critical evaluation. Forensic Sci. Int. 42, 201-213.

DOI: 10.1016/0379-0738(89)90087-X

GURLER, M., G. OZTURK, M. ZIYA KIR, Z. GINIS, G. ERDEN, S. AKYOL, M. KAYA, M. KARAPIRLI, O. AKYOL (2016): Simultaneous analysis of biochemical markers in vitreous humour and serum: a preliminary study on the effect of storage time at $-20{ }^{\circ} \mathrm{C}$. Aust. J. For. Sci., 48, 150-158.

DOI: $10.1080 / 00450618.2015 .1042046$

HANNA, P. E., J. E. C. BELLAMY, A. DONALD (1990): Postmortem eyefluid analysis in dogs, cats and cattle as an estimate of antemortem serum chemistry profiles. Can. J. Vet. Res. 54, 487-494.

INGHAM, A., R. BYARD (2009): The potential significance of elevated vitreous sodium levels at autopsy. J. For. Leg. Med. 16, 437-440.

DOI: 10.1016/j.jflm.2009.07.013

JAMES, R. A., P. A. HOADLEY, B. G. SAMPSON (1997): Determination of postmortem interval by sampling vitreous humour. Am. J. Forensic Med. Pathol. 18, 158-162.

DOI: $10.1097 / 00000433-199706000-00010$

MADEA, B., H. KAFERSTEIN, N. HERMANN, G. STICHT (1994): Hypoxanthine in vitreous humor and cerebrospinal fluid- a marker of postmortem interval and prolonged (vital) hypoxia? Remarks also on hypoxanthine in SIDS. Forensic Sci. Int. 65, 19-31.

DOI: 10.1016/0379-0738(94)90296-8

MADEA, B., C. HENSSGE, W. HONIG, A. GERBRACHT (1989): References for determining the time of death by potassium in vitreous humor. Forensic Sci. Int. 40, 231-243.

DOI: 10.1016/0379-0738(89)90181-3

McLAUGHLIN, P. S., B. G. McLAUGHLIN (1987): Chemical analysis of bovine and porcine vitreous humors: correlation of normal values with serum chemical values and changes with time and temperature. Am. J. Vet. Res. 48, 467-473.

MUNOZ BARUS, J. I., J. SUAREZ-PENARANDA, X. L. OTERO, M. S. RODRIGUEZCALVO, E. COSTAS, X. MIGUENS, L. CONCHERO (2002): Improved estimation of postmortem interval based on differential behavior of vitreous potassium and hypoxanthine in death by hanging, Forensic Sci. Int. 125, 67-74.

PALMIERE, C., P. MANGIN (2012): Postmortem chemistry update part II - Review. J. Leg. Med. $126,199-215$.

DOI: $10.1007 / \mathrm{s} 00414-011-0614-1$

ROGNUM, T. O., S. HOLMEN, M. A. MUSSE, P. S. DAHLBERG, A. STRAY-PEDERSEN, O. D. SAUGSTAD, S. H. OPDAL (2016): Estimation of time since death by vitreous humor hypoxanthine, potassium, and ambient temperature. Forensic Sci. Int. 262, 160-165.

DOI: 10.1016/j.forsciint.2016.03.001 
K. Severin et al.: Estimation of red deer (Cervus elaphus) post mortal interval

TUMRAMA, N. K., R. V. BARDALE, A. P. DONGRE (2011): Postmortem analysis of synovial fluid and vitreous humour for determination of death interval: A comparative study. Forensic Sci. Int. 204, 186-190.

DOI: $10.1016 /$ j.forsciint.2010.06.007

YAHIA, D., M. A. H. ABD EL-HAKIEM (2014): Biochemical analysis of synovial fluid, cerebrospinal fluid and vitreous humor at early postmortem intervals in donkeys. J. Adv. Vet. Res. 4, 6-11.

ZHU, B. L., T. ISHIKAWA, T. MICHIUE, S. TANAKA, D. ZHAO, D. R. LI, L. QUAN, S. ORITANI, H. MAEDA (2007): Differences in postmortem urea nitrogen, creatinine and uric acid levels between blood and pericardial fluid in acute death. Leg. Med. 9, 115-122.

DOI: 10.1016/j.legalmed.2006.10.002

ZILG, B., K.ALKASS, S. BERG, H. DRUID (2009): Postmortem identification of hyperglycemia. Forensic Sci. Int. 185, 89-95.

DOI: 10.1016/j.forsciint.2008.12.017

ZILG, B., K. ALKASS, S. BERG , H. DRUID (2016): Interpretation of postmortem vitreous concentrations of sodium and chloride. Forensic Sci. Int. 263, 107-113.

DOI: 10.1016/j.forsciint.2016.04.006

Received: 14 June 2017

Accepted: 24 October 2017

\begin{tabular}{l}
\hline SEVERIN, K., P. DŽAJA, M. ŠPERANDA, M. ĐIDARA, D. KONJEVIĆ, E. \\
ŚATROVIĆ, K. STARČEVIĆ: Procjena posmortalnog intervala u jelena običnog \\
(Cervus elaphus) na temelju biokemijskih vrijednosti staklovine korištenjem \\
linearne regresijske analize. Vet. arhiv 88, 511-519, 2018. \\
SAŽETAK \\
Staklovina je stabilna biološka tekućina koja je dobro zaštićena od kontaminacije i postmortalne \\
degradacije što je čini pogodnom u forenzičkoj patologiji za određivanje postmortalnog intervala (PMI). Ovo \\
je istraživanje provedeno kako bi se utvrdila korelacija između povećanja (PMI) i razina različitih biokemijskih \\
parametara staklovine (natrij, kalcij, magnezij, klorid, kalij, fosfor, AST, urea, kreatinin, ukupni protein, \\
glukoza, ukupni kolesterol). Procjena PMI-ja u jelena običnog od velikog je interesa za slučajeve protuzakonitog \\
lova. Za potrebe istraživanja staklovina je prikupljena od šest odstrijeljenih jelena. Nakon što su oči izvađene, \\
obložene su parafilmom i aluminijskom folijom te smještene u posudice pohranjene na stalnu temperaturu \\
od +4 ${ }^{\circ}$ C. Staklovina je prikupljena 8., 10., a zatim redovito svakih 10 sati do, konačno, 90 . sata nakon smrti. \\
Linearnom regresijskom analizom utvrđena je povezanost PMI-ja s kalijem, natrijem i kloridima (P<0,0001). \\
Ovo istraživanje pokazalo je da bi se biokemijska analiza staklaste tekućine mogla koristiti za određivanje PMI- \\
ja kod jelena običnog. \\
$\quad$ Ključne riječi: staklovina; kalij; natrij; klorid; jelen obični
\end{tabular}

Vet. arhiv 88 (4), 511-519, 2018 
